\title{
Efektivitas Teh Sibangun bangun Terhadap Volume ASI Pada Ibu Post SC Di Rumah Sakit Marinir Cilandak Tahun 2019
}

\author{
Vivi Silawati*, Ermi murnita \\ Fakultas Imu Kesehatan, Universitas Nasional, Jakarta, Indonesia \\ Corresponding author: Vivi Silawati (vivi.sila@civitas.unas.ac.id) \\ Received: Mei, 17 2020; Accepted: June, 26 2020; Published: September, 12020
}

\begin{abstract}
ABSTRAK
Ibu Post Sectio caesarea cenderung mengalami gangguan dalam memenuhi volume ASI. Tingginya angka prevalensi sectio caesarea berhubungan erat dengan waktu menyusui dini dan keberhasilan ASI ekslusif. Ibu bersalin dengan sectio caesaria sulit untuk leluasa menyusui dini disebabkan oleh nyeri pada luka operasi. Rentang waktu yang panjang pada awal menyusui bayi mengakibatkan kurangnya rangsangan terhadap payudara untuk memproduksi ASI, yang berakibat rendahnya volume ASI. Tujuan penelitian ini untuk mengetahui efektivitas teh Sibangun bangun tehadap volume ASI pada ibu post sectio caesarea di Rumah sakit Marinir Cilandak Tahun 2019. Penelitian ini menggunakan quasi-experiment dengan perlakuan sebelum dan sesudah.Sampel dalam penelitian ini berjumlah 30 orang yang terdiri dari $15 \mathrm{Ibu}$ Post Sectio caesarea kelompok eksperimen dan 15 Ibu post Sectio caesarea kelompok control, Teknik pengambilan sampel menggunakan Purposive sampling. Instrumen penelitian menggunakan observasi langsung dan Breast pump. Data dianalisis menggunakan dekriptif statistik dan inferensial statistik yaitu paired t-tes. Hasil penelitian menunjukkan bahwa ada perbedaan yang signifikan pada volume ASI sebelum dan sesudah diberikan teh Sibangun bangun pada kelompok eksperimen dan kelompok kontrol. Pemberian Teh Sibangun bangun secara rutin diminum 2 kali sehari selama 30 hari pada ibu post sectio caesarea efektif meningkatkan volume ASI, Bidan diharapkan untuk lebih baik lagi memberikan konseling pada ibu post sectio caesarea mengenai pemenuhan gizi seimbang dengan penambahan the sibangunbangun dalam meningkatkan volume ASI.
\end{abstract}

Kata Kunci: Volume ASI, Teh Sibangun bangun, Post sectio caesarea

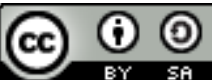

This is an open-acces article distributed under the terms of the Creative Commons Attribution-ShareAlike 4.0 International License.

\section{PENDAHULUAN}

Masa neonatal adalah waktu yang kritis untuk kelangsungan hidup anak-anak. Pelaksanaan inisiasi menyusui dini dan pemberian ASI eksklusif, meningkatkan sistem kekebalan tubuh terhadap infeksi. Menurut data WHO (2016) cakupan pemberian ASI ekslusif diseluruh dunia selama periode 2007-2014 hanya sekitar 36\% (dalam IBI, 2019).

Hasil Riskesdas 2018 proporsi pola pemberian ASI pada bayi umur 0-5 bulan di Indonesia sebanyak 37,3\%, ASI ekslusif 9,3\%, ASI parsial, dan 3,3\% ASI predominan (Kemenkes RI, 2018). Makanan prelakteal adalah makanan atau minuman yang diberikan kepada bayi sebelum diberikannya ASI. 
Menurut Riskesdas 2013, persentase tertinggi makanan prelakteal yang diberikan kepada bayi baru lahir di Indonesia tahun 2013 adalah susu formula sebesar 79,8\% (Riskesdas, 2013). Inisiasi menyusu dini dan pemberian ASI eksklusif diatur oleh WHO dan kebijakan pemerintah. WHO merekomendasikan bagi ibu untuk menyusui bayinya segera 1 jam setelah kelahiran, dilanjutkan secara eksklusif selama 6 bulan pertama, dan kombinasikan dengan makanan pendukung hingga usia 2 tahun (WHO, 2018).

Situasi gizi balita di dunia saat ini sebanyak 155 juta balita pendek (stunting), 52 juta balita kurus (wasting), dan 41 juta balita gemuk (overweight). Di Indonesia, berdasarkan hasil Riskesdas 2018, 17,7\% balita mengalami gizi buruk dan gizi kurang, 30,8\% balita sangat pendek dan pendek, 10,2\% balita sangat kurus dan kurus, dan $8 \%$ balita gemuk (Riskesdas, 2018).

Pemberian ASI pada bayi erat hubungannya dengan kondisi gizi kurang dan gizi lebih (gemuk) pada anak. ASI merupakan sumber energi dan nutrisi terpenting pada anak usia 6-23 bulan. ASI memenuhi lebih dari setengah kebutuhan energi pada anak usia 6-12 bulan dan sepertiga dari kebutuhan energi pada anak usia 12-24 bulan. ASI juga merupakan sumber nutrisi yang penting pada proses penyembuhan ketika anak sakit (WABA, 2018)

Pemberian ASI dapat menurunkan risiko penyakit infeksi akut seperti diare, pneumonia, infeksi telinga, haemophilus influenza, meningitis, dan infeksi saluran kemih. Bayi yang tidak diberi ASI akan rentan terhadap penyakit infeksi. Kejadian bayi dan balita menderita penyakit infeksi yang berulang akan mengakibatkan terjadinya balita dengan gizi buruk dan kurus (Alan et al., 2013)

Prevalensi Sectio caesarea di Indonesia adalah sekitar 15,3\% dari 20591 persalinan yang secara khusus terakumulasi 19,9\% di DKI Jakarta (Riskesdas, 2013). Dari hasil studi pendahuluan pada buan April 2019, Pada tahun 2018 tercatat 304 sectio caesarea dari 402 persalinan di Rumah Sakit Marinir Cilandak. Rumah sakit telah mensosialisasikan program pemberian ASI dini dan eksklusif; Namun, masih ada beberapa ibu menyusui masih memberikan selain ASI dengan alasan produksi ASI masih kurang.

Daun Sibangun bangun adalah salah satu cara untuk membantu meningkatkan volume ASI melalui komposisi Lactogogum. Daun ini telah menjadi kebutuhan pokok bagi wanita Batak yang baru saja melahirkan bayi mereka (Hidayat et al., 2014). Daunnya dapat dikonsumsi dalam bentuk sup, jus, dan teh (yang paling efisien dari semuanya). Satu bungkus daun Sibangun bangun diseduh dengan air panas $200 \mathrm{~mL}$ kemudian disaring dan dikonsumsi $2 x$ sehari, pagi dan sore setelah makan. Selanjutnya, penelitian ini menilai efektivitas Teh Sibangun bangun dalam meningkatkan volume ASI ibu post Sectio caesarea di Rumah Sakit Marinir Cilandak 2019.

\section{METODE}

Metode penelitian ini menggunakan Quasi Eksperimen control Time Series desaign digunakan dalam penelitian ini dengan berbagai pengukuran data melalui analisis kuantitatif. Pengukuran bertujuan untuk memahami perbedaan volume ASI dari 15 responden post SC pada kelompok kasus dan 15 responden post SC pada kelompok kontrol dengan . Responden dipilih melalui purposive sampling di mana setiap Responden disaring melalui kriteria inklusif dan eksklusif yang sudah ditentukan. Data ditabulasi menggunakan Microsoft Excel 2014 dan dianalisis secara statistik dengan SPSS 24. Efek teh Sibangun bangun ditemukan melalui uji uji paired T test dan T Independent.

\section{HASIL PENELITIAN}

Penelitian dilakukan di Rumah Sakit Marininir Cilandak pada tanggal 28 Mei hingga 15 Juli 2019 selama 6 minggu. Semua ibu post Sectio caesarea yang memenuhi kriteria inklusif 
dan eksklusif diukur volume ASInya dan pada kelompok kasus diberikan teh Sibangun bangun.

Tabel 1. Data Karakteristik Responden

\begin{tabular}{lccc}
\hline & Karakteristik Ibu & Frekuensi (f) & Persentase (\%) \\
\hline Usia & & & \\
\hline \multirow{4}{*}{ Paritas } & $20-35$ tahun & 23 & $77 \%$ \\
& $>35$ tahun & 7 & $23 \%$ \\
\hline & Primipara & 6 & \\
& Multipara & 24 & $20 \%$ \\
\hline
\end{tabular}

Dari 30 responden, sebagian besar berada pada rentang usia 20-35 tahun sebanyak 77\% dengan status multipara sebanyak $80 \%$

Tabel 2. Jumlah Volume ASI sebelum diberikan Teh Sibangun bangun pada kelompok Eksperimen dan kelompok Kontrol

\begin{tabular}{lrrccc}
\hline Kelompok & Mean & Median & Std.Deviasi & Minimum & Maksimum \\
\hline Eksperimen & 5.47 & 5.70 & 2.282 & 0 & 10 \\
Kontrol & 5.89 & 5.70 & 1.768 & 3 & 10 \\
\hline
\end{tabular}

Jumlah volume ASI pada ibu post-SC didapatkan hasil sebanyak $5.47 \pm 2.282 \mathrm{~mL}$ untuk kelompok kasus; sedangkan 5,89 $\pm 1,768 \mathrm{~mL}$ untuk kelompok kontrol.

Tabel 3. Perbedaan Volume ASI Sebelum dan Sesudah minum Teh Sibangun bangun pada kelompok Eksperimen

\begin{tabular}{lllll}
\hline \multirow{2}{*}{ Kelompok Kasus } & \multicolumn{3}{c}{ Volume ASI } & \multirow{2}{*}{ P value } \\
\cline { 2 - 4 } & Mean & SD & N & \\
\hline Sebelum & 5.473 & 2.281 & \multirow{2}{*}{0.000} \\
Sesudah & 327.927 & 26.595 & 15 & \\
\hline
\end{tabular}

Ada perbedaan signifikan yang diamati pada volume ASI sebelum konsumsi teh Sibangun bangun pada kelompok kasus dengan nilai P 0,000. Dengan kenaikan volume ASI sebanyak 322.454 .

Tabel 3 Perbedaan Volume ASI Sebelum dan Sesudah minum Teh Sibangun bangun pada kelompok Kontrol

\begin{tabular}{lllll}
\hline \multirow{2}{*}{ Kelompok Kontrol } & \multicolumn{3}{c}{ Volume ASI } & \multirow{2}{*}{ P value } \\
\cline { 2 - 5 } & \multicolumn{1}{c}{ Mean } & \multicolumn{1}{c}{ SD } & N & \\
\hline Sebelum & 5.893 & 1.768 & \multirow{2}{*}{0.000} \\
Sesudah & 198.570 & 24.860 & 15 & \\
\hline
\end{tabular}

Ada perbedaan signifikan yang diamati pada volume ASI sebelum konsumsi teh Sibangun bangun pada kelompok kasus dengan nilai P 0,000. Dengan kenaikan volume ASI sebanyak 192.677. 


\section{PEMBAHASAN}

Dari periode pengamatan, tercatat bahwa mayoritas responden dalam kelompok usia 20 -35 tahun adalah 23 responden (77\%), sementara sebagian kecil responden berada dalam kelompok usia> 35 tahun yang sebanyak 7 responden (23\%). Menurut Hidayati (2012), 20-35 tahun adalah periode reproduksi yang sehat untuk kehamilan, persalinan, dan menyusui karena memungkinkan dukungan menyusui eksklusif. Di sisi lain, <20 tahun dianggap masih belum matang secara fisik, mental, dan psikologis dalam menghadapi persalinan, kehamilan, dan menyusui.

Mayoritas responden termasuk dalam kelompok paritas multipara dengan 24 orang $(80 \%)$, sementara proporsi kecil adalah primipara, yaitu 6 responden $(20 \%)$. Sebuah penelitian yang dilakukan Ida ayu (2015) menguatkan gagasan ini dengan fakta bahwa onset laktasi antara primipara dan multipara keduanya memiliki onset laktasi yang cepat sehingga paritas tidak mempengaruhi terjadinya onset laktasi $(p>0,05)$.

Bahwa ada perbedaan yang signifikan pada volume ASI sebelum konsumsi teh Sibangun bangun pada kasus dan kelompok kontrol berdasarkan pengukuran ( $\mathrm{P}$ value 0,000 ). Academy of Pediatrics mengatakan adanya peningkatan ASI dari hari ke hari, volume ASI ratarata pada hari 1 adalah $7 \mathrm{~mL}$, hari 2 adalah $14 \mathrm{~mL}$, dan hari 3 adalah $38 \mathrm{~mL}$.

Berdasarkan tabel 3, dapat disimpulkan bahwa volume ASI asupan teh pra-Sibangun bangun untuk ibu pasca SC sama sedikit jumlahnya baik sebagai kelompok eksperimen atau kelompok kontrol. Hasilnya menggambarkan 5,47 \pm 2,282 $\mathrm{mL}$ dengan kisaran 0-10 untuk kelompok kasus; sedangkan 5,89 $\pm 1,768 \mathrm{~mL}$ dengan kisaran 3-10 untuk kontrol.

Menurut Desmawati (2010), 54\% dari ibu post sectio caesarea tidak benar dalam posisi menyusui dan 55\% mengalami mobilisasi pasif akibat nyeri luka operasi. Jika dibandingkan dengan teori yang ada, volume ASI pada hari pertama menyusui pada ibu post Sectio caesarea di rumah sakit Marinir cenderung lebih rendah dari normal, ini diasumsikan disebabkan oleh rasa sakit, ketidakmampuan untuk memobilisasi secara aktif, dan stres.

Berbagai penelitian lain juga menemukan hasil yang sama, yaitu volume ASI pada awal menyusui pada ibu pasca operasi volume ASI sedikit namun sangat dipengaruhi oleh rasa sakit, posisi nyaman, gizi, dan keterlambatan rawat gabung karena ibu masih di ruang observasi. Responden dari kelompok kasus terbukti mengeluarkan lebih banyak volume ASI daripada kelompok kontrol (327.927 $\pm 26.595 \mathrm{~mL}$ vs $189.570 \pm 24.860 \mathrm{~mL})$ setelah konsumsi teh Sibangun bangun. Peningkatan volume ASI yang lebih tinggi pada kelompok responden yang minum Teh Sibangun bangun disebabkan oleh lactogogum yang terkandung didalamnya yang meningkatkan tingkat sekresi dan produksi susu (Rizal, 2015).

Daun Sibangun bangun mengandung lactogogum dengan 10 komponen aktif dan asam lemak rantai ganda yang berhubungan langsung dengan kelenjar susu sehingga mampu merangsang dan meningkatkan produksi ASI. Ibu yang mengkonsumsi daun Sibangun bangun akan merasa lebih segar dan tidak lelah. Penelitian tentang pemanfaatan konsumsi daun Sibangun bangun selama laktasi menunjukkan bahwa daun yang dikonsumsi dapat meningkatkan volume total ASI dan berat bayi (Santosa, 2005). Daun Sibangun bangun memiliki nutrisi tinggi, terutama zat besi dan beta karoten (Tiurlan, 2013)

Berdasarkan Rizal (2015) ibu bersalin yang diberi daun Sibangun bangun hingga 150 gram setiap hari selama 30 hari akan meningkatkan volume ASI hingga 65\%. Sejalan dengan hasilnya, Tiurlan (2013) mengatakan bahwa 4 jam setelah pemberian daun Sibangun bangun, produksi ASI akan meningkat sebesar 47,4\%.

Peningkatan ASI juga terjadi pada responden yang tidak mengkonsumsi teh karena volume ASI akan meningkat pada ibu menyusui secara fisiologis mulai dari minggu pertama hingga akhir tahun pertama dan akan menurun kembali, hal ini disampaikan oleh ikatan dokter anak sesuai produksi ASI pada hari pertama dan kedua memang sangat sedikit namun produksi akan meningkat dengan cepat pada hari kelima dan tetap stagnan sejak minggu keenam dan 
seterusnya (IDAI, 2013). Pada minggu pertama kelahiran, volume ASI sekitar 50-100 mL dan meningkat pada minggu kedua mencapai 400-500 mL (Elisabeth, 2015).

\section{KESIMPULAN}

1. Para responden sebagian besar berada dalam kisaran 20-35 tahun dan paritas multipara dengan prevalensi $77 \%$ dan $80 \%$

2. Volume ASI pada ibu post SC yang diberikan the Sibangun-bangun naik secara signifikan dibandingkan yang tidak mendapat teh Sibangun-bangun

3. Adanya perbedaan yang signifikan antara volume ASI ibu post Sectio caesarea yang diberikan teh sibangun-bangun dengan ibu yang tidak diberikan dengan $\mathrm{P}$ value 0.000 .

Semua penyedia layanan kesehatan, terutama dari paviliun Anyelir RS Marinir Cilandak, diharapkan dapat memfasilitasi dan mengedukasi pasien tentang pentingnya pemberian ASI eksklusif dini dan teh Sibangun bangun sebagai salah satu pilihan dalam meningkatkan produksi ASI pada ibu-ibu Post Sectio Caesarea.

\section{REFERENSI}

Alan R. Tumbelaka dan Mulya R. Karyanti.. 2013. Air Susu Ibu dan Pengendalian Infeksi. IDAI

Christin Marganingsih Santosa,Triana Hertiani. 2005. Kandungan senyawa kimia dan efek ekstrak air Daun Bangun-bangun (Coleus amboinicus, L.) pada aktivitas fagositosis netrofil tikus putih (Rattus norvegicus). Majalah Farmasi Indonesia, 16 (3), 141 - 148, 2005

Desmawati. (2010). Perbedaan waktu pengeluaran ASI ibu post sectio caesarea dengan post partum normal. Jurnal Bina Widya Universitas Pembangunan Nasional Veteran Jakarta.

Elisabeth, Siwi Walyani. Endang Puroastuti. (2015). Asuhan Kebidanan Masa Nifas dan Menyusui. Yogyakarta : Pustaka Baru Press

Hidayati. (2012). Usia ibu dalam pemberian ASI Ekslusif.

Ida Ayu Sri Puspa Ningsih. 2015. Hubungan Paritas Dengan Onset Laktasi Pada Ibu Post Partum Di Rs Pku Muhammadiyah Yogyakarta Tahun 2015. Http://Digilib.Unisayogya.Ac.Id/70/1/Naskah\%20publikasi.Pdf

Ikatan Bidan Indonesia. 2018. Pekan ASI Se-Dunia (World Breastfeeding Week. IBI. https://www.ibi.or.id/id/article_view/A20180808002/pekan-asi-se-dunia-worldbreastfeeding-week.html.

Kementerian Kesehatan Republik Indonesia. 2018. Menyusui Sebagai Dasar Kehidupan. Infodatin, Kemenkes RI. ISSN 2442-7659.

Kementerian Kesehatan RI. 2018. Paparan Hasil Utama Riset Kesehatan Dasar 2018.

Kementerian Kesehatan RI. 2013. Riset Kesehatan Dasar 2013. Jakarta: Kementerian Kesehatan RI.

Kementerian Kesehatan RI. 2018. Riset Kesehatan Dasar 2018. Jakarta: Kementerian Kesehatan RI.

Syarief,H., Damanik, R.M., Sinaga, T., \& Doloksaribu, T. H. (2014). Pemanfaatan Daun Bangun-Bangun dalam Pengembangan Produk Makanan Tambahan Fungsional untuk Ibu Menyusui. Jurnal Ilmu Pertanian Indonesia, 19(1),38-42. Retrievedfrom https://journal.ipb.ac.id/index.php/ JIPI/article/view/8404

Tiurlan Farida Hutajulu, Lukman Junaidi. 2013. Manfaat Ektrak Daun Bangun-bangun Untuk Meningkatkan Produksi Air Susu Induk Tikus. Jurnal Riset Industri Vo; 7 No. 1 Tahun 2013. https://media.neliti.com/media/publications/178604-ID-none.pdf

WABA. 2018. Breastfeeding: Foundation of Life. http://worldbreastfeeding week.org 
WHO. 2018. Infant and Young Child Feeding. http://www.who.int/news-room/factsheets/detail/infant-and young-child-feeding

WHO. 2018. World Breastfeeding Week 2018. http://www.who.int/newsroom/commentaries/detail/worldbreastfeeding-week-2018 